\title{
A Bark Thickness Model for White Spruce in Alaska Northern Forests
}

\author{
Thomas Malone and Jingjing Liang \\ Department of Forest Sciences, University of Alaska Fairbanks, P.O. Box 757200, Fairbanks, AK 99775, USA \\ Correspondence should be addressed to Jingjing Liang, jliang@alaska.edu
}

Received 11 June 2009; Revised 4 September 2009; Accepted 27 October 2009

Recommended by Han Chen

\begin{abstract}
Here we developed a simple linear model to estimate white spruce bark thickness in the northern forests of Alaska. Data were collected from six areas throughout interior and southcentral Alaska. Geographic variation of bark thickness was tested between the Alaska statewide model and for each geographic area. The results show that the Alaska statewide model is accurate, simple, and robust, and has no practical geographic variation over the six areas. The model provides accurate estimates of the bark thickness for white spruce trees in Alaska for a wide array of future studies, and it is in demand by landowners and forest managers to support their management decisions.
\end{abstract}

Copyright (C) 2009 T. Malone and J. Liang. This is an open access article distributed under the Creative Commons Attribution License, which permits unrestricted use, distribution, and reproduction in any medium, provided the original work is properly cited.

\section{Introduction}

Estimating bark thickness is an important part of the research of forest growth and yield, economics, and fire control. Timber volume and value cannot be correctly estimated without knowing the thickness of bark (Meyer [1]). Although bark accounts for a small percentage of tree volume, managers know that the amount of bark purchased with standing trees matters to their bottom line (Marden et al. [2]). For many years, bark had been an unwanted byproduct of milling operations, since its disposal, typically through burying or combustion, often increases the cost of operations (Haygreen and Bowyer [3]). Bark has been used for centuries, on a small scale, for medicinal purposes, food, baskets, boats, and tannins (Small [4]). As mill operators and researchers have determined the properties of bark, several new uses have been identified. The most basic use of bark is to produce energy or heat through combustion. Bark can also be used as a landscape material. Industrial operations continue to develop uses for large quantities of bark.

The outside bark volume of standing trees can be estimated from measurements of their height and diameter at breast height outside bark (dbh). With bark thickness models, the volume of wood inside the bark can also be estimated for forest growth, productivity, and economic analysis (Farr [5]); therefore, models that provide accurate estimates of the amount of bark in standing trees are useful.

Bark thickness varies by tree species. For example, white spruce (Picea glauca (Moench) Voss) and black spruce (Picea mariana (Mill.) B.S.P.) are considered thin-bark species with average thickness of 0.6 to $1.3 \mathrm{~cm}$ (Viereck and Little [6]), while white fir (Abies concolor (Gord. and Glend.) Hildebr.) is a thick-bark species with an average bark thickness of 10.2 to $17.8 \mathrm{~cm}$ (Harlow et al. [7]).

As the most valuable commercial species in Alaska northern forests, white spruce accounts for 64-81 percent of the commercial volume of this biome (Hutchison [8]). The northern forests of Alaska cover all the forest types of interior and southcentral Alaska including the boreal forests but excluding the coastal forests. White spruce grows throughout the interior and southcentral areas from the Canadian border in the east to the Bering Sea in the west and from the Kenai Peninsula in the south to the Brooks Range in the north (Harlow et al. [7]). White spruce grows on a wide variety of sites, from sand, silt, and clay, to organic matter. White spruce is a commercially valued species. It is widely used for dimension lumber, paneling, pulpwood, and firewood (Harlow et al. [7]).

Unfortunately, study of bark thickness is limited for species in Alaska. Yarie et al. [9] developed equations to 


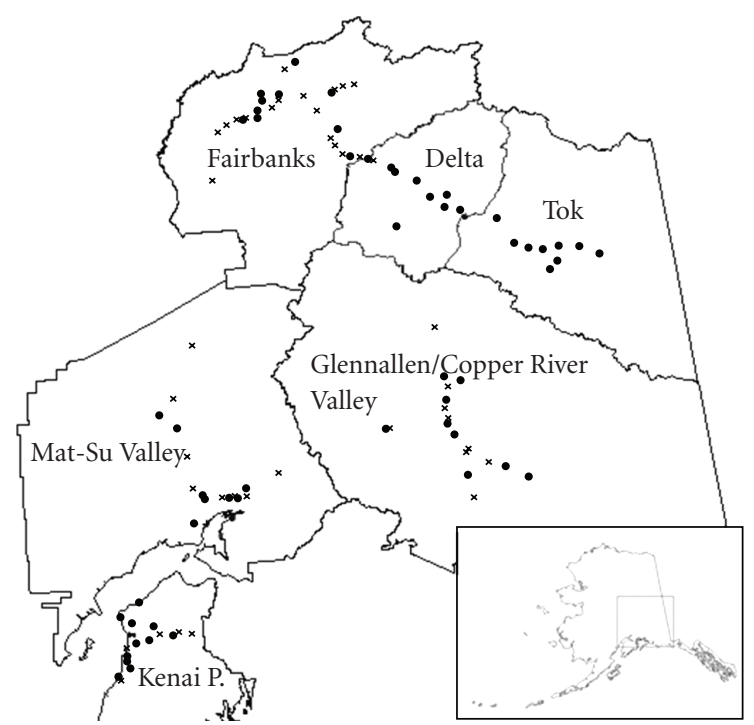

Figure 1: Geographic distribution of the 60 sample sites (dots) and 15 post-sample validation sites (Xs) and their relative locations within the state of Alaska (inset).

estimate bark biomass for species native to interior Alaska. The results, due to the limited sample size and geographic coverage, are susceptible to significant bias when applied statewide.

For management purposes, the State of Alaska Division of Forestry (DOF) has divided interior and southcentral Alaska region into six geographic areas: Delta, Glennallen/Copper River Valley, Fairbanks, Kenai Peninsula, MatSu Valley, and Tok (Figure 1). Each area has adopted a variety of bark thickness and volume models. None of these models, however, was developed for statewide application.

The objective of this study was to develop a single model to estimate bark thickness of white spruce in Alaska. A universal model covering all six DOF areas in interior and southcentral Alaska was developed for simplicity and maximum geographic coverage. A bark thickness equation was developed for each of the six DOF areas based on samples from that area. The statewide model was tested against the six area models for robustness to geographic variation.

\section{Data and Method}

We selected 600 white spruce bark thickness samples from the six geographic areas of interior and southcentral Alaska (Figure 1).

Within each of these areas, we randomly located 10 sites representative of the forest types of the area. For budget and safety reasons, the sites were selected from $30-\mathrm{km}$ wide corridors surrounding the existing highways. All the sites were classified as commercial forest land (Helms [10]). Within each site, 10 trees were sampled, for a total of 600 trees sampled. Sample trees at each site were randomly selected from each of these crown classes: dominant, codominant, intermediate, and suppressed trees. Bark thickness was measured using a hand-held Swedish bark gauge at 3 equidistant points around the stem at breast height, to the nearest $1.27 \mathrm{~mm}$ (0.05 inch). To reduce measurement errors, all bark thickness measurements used in this data set were collected by a single individual. Table 1 provides summary statistics of dbh and bark thickness data for the dataset.

The bark thickness model has the following form:

$$
y=\beta_{0}+\beta_{1} x+e,
$$

where $y$ is bark thickness $(\mathrm{cm})$ and $x$ is $\mathrm{dbh}(\mathrm{cm})$. $\beta$ s are parameters estimated from the Generalized Least Squares (GLS, Nelder and Wedderburn [11]) regression, and $e$ is the error term assumed to follow a normal distribution independent of the geographic areas. Geographic difference was tested by comparing the predicted bark thickness values for each geographic area with those predicted by the statewide models (Figure 3).

The accuracy of this model was determined by the prediction errors, the difference between the actual bark thickness and the predicted value. The test was done on 247 post-sample trees (see the summary statistics in Table 1). These post-sample measurements were obtained from across the boreal forest region of Alaska (Figure 1). For validation purposes, all post-sample measurements were collected from forest plots with different locations and characteristics from the sample plots. The predictions of the Alaska model were further compared against two existing bark thickness models calibrated for white spruce in British Columbia and the Lake States (Kozak and Yang [12], Gevorkiantz and Olsen [13]). To test if the 247 post-sample trees could further improve the model, the post-sample data were added to the original sample to form a larger sample that was composed of 847 tree records. A reference model was estimated from the larger sample and was compared against the Alaska statewide model to see if there was any significant difference in the parameters.

\section{Results}

The parameters of the Alaska model were highly significant $(P<.01)$, and the coefficient of determination $\left(R^{2}=0.63\right)$ represented a good fit (Table 2). Figure 2 shows that the residuals for the Alaska model were normally distributed, with no discernable pattern. There were a few suspicious outlying residuals but their standard influence on predicted value (Belsley et al. [14]) suggests that none of them were influential outliers.

Figure 3 shows that the predicted bark thickness for six individual areas all fell within the $90 \%$ confidence interval of the predicted values of the Alaska model. In other words, within the range of our sample, the predictions between the Alaska model and the models developed for the six areas were nearly the same, and therefore the Alaska model developed in this study was an accurate estimate of white spruce bark thickness across the boreal region of Alaska.

Figure 4 shows the errors in predicting the bark thickness from dbh on 247 post-sample white spruce bark thickness records. The predictions of this model all fell within the 95\% confidence interval of the observations. The reference model 
TABLE 1: Summary statistics of sample and post-sample tree records.

\begin{tabular}{lcccc}
\hline & \multicolumn{2}{c}{ Sample } & \multicolumn{2}{c}{ Post-sample } \\
statistic & bark thickness $(\mathrm{cm})$ & $\mathrm{dbh}(\mathrm{cm})$ & bark thickness $(\mathrm{cm})$ & 1.02 \\
Mean & 1.12 & 23.83 & 0.30 & 23.47 \\
SD & 0.41 & 9.55 & 1.85 & 8.92 \\
Max & 2.54 & 64.77 & 0.46 & 48.51 \\
Min & 0.30 & 9.14 & 247 & 9.14 \\
$n$ & 600 & 600 & & 247 \\
\hline
\end{tabular}

TABLE 2: Parameters of the six area models and the statewide model to estimate the bark thickness of white spruce in Alaska northern forests.

\begin{tabular}{|c|c|c|c|c|}
\hline Model & Estimated right hand side of equations & $R^{2}$ & $n$ & RMSE \\
\hline Copper River Valley & $0.412^{*}+0.037 \times \mathrm{dbh}^{*}$ & 0.77 & 100 & 0.030 \\
\hline Delta area & $0.115^{*}+0.043 \times \mathrm{dbh}^{*}$ & 0.69 & 100 & 0.086 \\
\hline Fairbanks area & $0.239^{*}+0.034 \times \mathrm{dbh}^{*}$ & 0.74 & 100 & 0.054 \\
\hline Kenai Peninsula & $0.313^{*}+0.038 \times \mathrm{dbh}^{*}$ & 0.76 & 100 & 0.028 \\
\hline Mat-Su Valley & $0.314^{*}+0.028 \times \mathrm{dbh}^{*}$ & 0.59 & 100 & 0.042 \\
\hline Tok area & $0.247^{*}+0.034 \times \mathrm{dbh}^{*}$ & 0.54 & 100 & 0.070 \\
\hline Alaska & $0.303^{*}+0.035 \times \mathrm{dbh}^{*}$ & 0.63 & 600 & 0.064 \\
\hline
\end{tabular}

Note: Response variable is the thickness of bark $(\mathrm{cm})$, dbh stands for the diameter-at-breast height $(\mathrm{cm}) .{ }^{*}$ represents that the coefficient is significant at 0.01 level. $R^{2}$, coefficient of determination; $n$, number of sampled trees; RMSE, root mean square error.

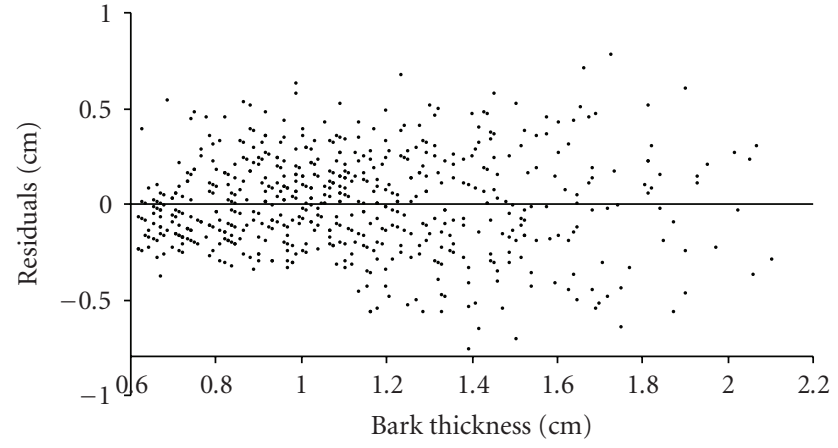

FIGURE 2: Residual plot of the Alaska bark thickness model.

estimated from the larger sample (the Alaska model plus the 247 post-sample data) was almost the same as the present model, viz. $P=1.00$ for the test of the hypothesis that the difference between the coefficients from the two models was zero. Therefore, the present Alaska statewide model was representative of the study area and adding the post-sample records to the sample would not further improve the model.

In comparison, the model developed for commercial trees in British Columbia (Kozak and Yang [12]) underestimated bark thickness. As trees grow larger, the predictions errors became more significant. The Lake States model (Gevorkiantz and Olsen [13]), conversely, overestimated diameter inside bark of white spruce trees, and for trees larger than $24 \mathrm{~cm}$. in diameter, the errors were significant at the 5\% level. It suggests that even though both the British Columbia and Lake States models were fit for white spruce, they are not capable of providing accurate estimates of bark thickness of white spruce trees in Alaska's northern forests, for which

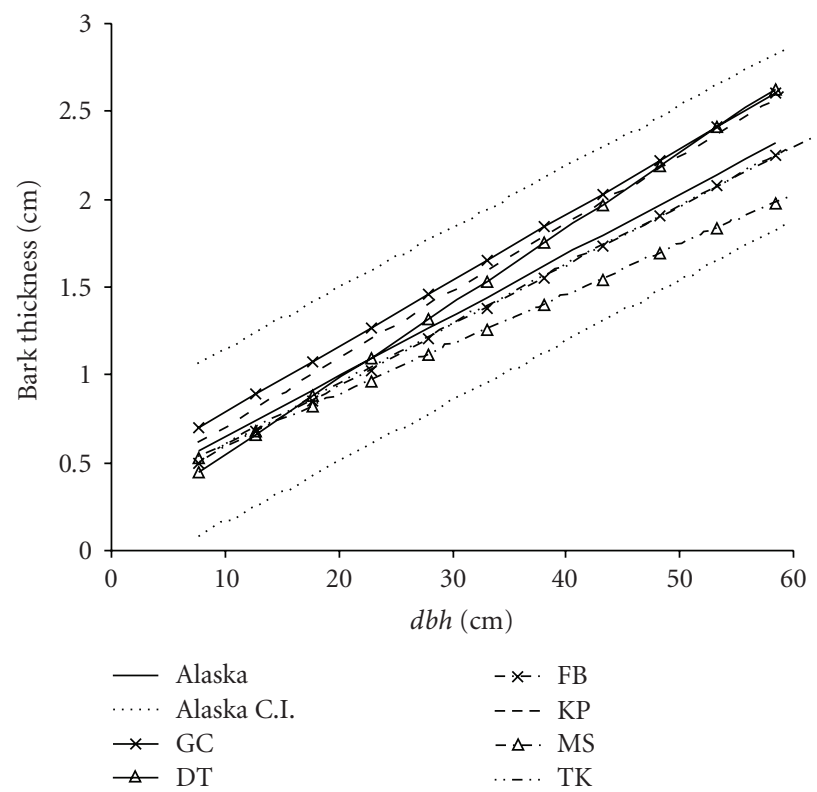

FIGURe 3: Predicted bark thickness $(\mathrm{cm})$ from the Alaska model (Alaska) with $90 \%$ confidence interval (Alaska C.I.), and from the models fit for the six individual areas: Glennallen/Copper River Valley (GC), Delta (DT), Fairbanks (FB), Kenai Peninsula (KP), Mat-Su Valley (MS), and Tok (TK).

climate conditions and growing season differ considerably (Van Cleve et al. [15]).

\section{Discussion and Conclusion}

We developed a model to estimate bark thickness of white spruce in Alaska northern forests. The model was 


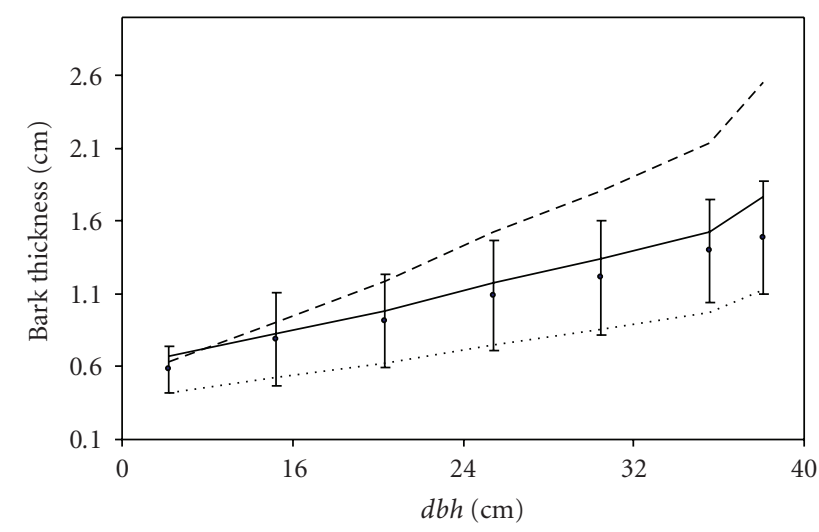

- Observed, with 95\% C.I.

— Predicted, Alaska model

..... Predicted, British Columbia model

- - - Predicted, Lake States model

Figure 4: Average predicted and observed (with 95\% confidence interval) bark thickness $(\mathrm{cm})$, on 247 post-sample white spruce trees in Alaska. Predictions were obtained with British Columbia model, Lake States model, and the Alaska model presented here.

TABLE 3: Differences between predicted and observed bark thickness with the Alaska model on post-sample white spruce trees.

\begin{tabular}{lccc}
\hline Area & mean $(\mathrm{cm})$ & std $(\mathrm{cm})$ & $n$ \\
\hline Copper River Valley & 0.16 & 0.02 & 50 \\
Delta area & 0.13 & 0.20 & 15 \\
Fairbanks area & 0.31 & 0.16 & 82 \\
Kenai Peninsula & 0.09 & 0.06 & 50 \\
Mat-Su Valley & 0.09 & 0.02 & 50 \\
Tok area & - & - & - \\
Overall & $\mathbf{0 . 1 1}$ & $\mathbf{0 . 1 1}$ & $\mathbf{2 4 7}$ \\
\hline
\end{tabular}

Note: std, standard deviation; $n$, number of sampled trees. There is no postsample data from the Tok area.

tested and found to be more accurate for Alaska over existing models calibrated for other regions (Figure 4). This model covers all the six areas of Alaska northern forests: Delta area, Glennallen/Copper River Valley, Fairbanks area, Kenai Peninsula, Matanuska-Susitina Valley, and Tok area. Although the statewide model may be less accurate than an area model for that specific area, the errors of the statewide model were almost negligible for each area (Table 3). The prediction errors were close to the measurement errors, and a single statewide model was much simpler than several area models especially for statewide studies. The systematic overestimation by the statewide model for the post-sample trees (Figure 4) was presumably caused by the fact that the post-sample data were collected in the winter time, while all the sample data were collected in summer time. Thickness of bark is usually larger in summer time than in winter when the trees are frozen (e.g., Zweifel and Häsler [16]).

This model is able to estimate white spruce bark thickness with a wide range of diameters from 8 to $66 \mathrm{~cm}$. Since white spruce is a thin-bark species and its stem tapers quickly from a small root collar at the base, the model can be used to estimate bark thickness at various tree heights and to address wood volume along the stem inside bark. Meyer [1] used dbh and bark thickness measurements to estimate volume along the stem inside bark of various tree species, and the results show that the predicted volumes inside bark are close to the observed values.

Researchers have attempted to improve bark thickness models by using various forms of dbh (quadratic, exponential), or adding other attributes such as tree age, height, and site characteristics (e.g., Hale [17], Dimitrov [18]). This study considered $\mathrm{dbh}$ as the only necessary explanation variable due to the following four reasons. First, research on bark thickness of coniferous trees (e.g., Kozak and Yang [12]) shows that bark thickness is very linear to the diameter at breast height and the ratio of diameter inside bark to outside bark is close to constant along the stem. Second, tree age and height are highly correlated with $\mathrm{dbh}$, and putting them in the model could cause multicollinearity-related problems. Third, a complex model is less useful because it costs more to measure other tree and site attributes. Finally, the simple linear model proposed here was capable of producing accurate predictions of bark thickness of post-sample trees (Figure 4).

Estimates for volume of white spruce in Alaska have been developed (Gregory and Haack [19], Larson and Winterberger [20]). Neither of these publications, however, offers models that are widely accepted to estimate the volume of white spruce in Alaska, because of their limited geographic sample coverage, and lack of control for bark thickness. With the bark thickness model developed in this study, previous white spruce volume models could be updated and improved. As a follow up of this study, an Alaska statewide volume model for white spruce is currently under development by the authors.

\section{Acknowledgment}

We are obligated to Carol E. Lewis and Edmond C. Packee for supporting this bark thickness research. This research was also supported in part by the United States Department of Agriculture, McIntire-Stennis Act Fund ALK-03-12, and by the School of Natural Resources and Agricultural Sciences, University of Alaska Fairbanks. We thank the associate editor, Han Chen, and an anonymous reviewer for their helpful comments.

\section{References}

[1] H. A. Meyer, "Bark volume determination in trees," Journal of Forestry, vol. 44, pp. 1067-1070, 1946.

[2] R. M. Marden, D. C. Lothner, and E. Kallio, Wood and Bark Percentages and Moisture Content of Minnesota Pulpwood Species, Research Paper NC-114, USDA, Forest Service, 1975.

[3] J. G. Haygreen and J. L. Bowyer, Forest Products and Wood Science, Iowa State University Press, Ames, Iowa, USA, 3rd edition, 1996.

[4] H. B. Small, Forest Trees, Timber, and Forest Products, Dawson Brothers, Montreal, Canada, 1884. 
[5] W. A. Farr, Board-Foot Tree Volume Tables and Equations for White Spruce in Interior Alaska, Research Note PNW-59, USDA, Forest Service, 1967.

[6] L. A. Viereck and E. L. Little, Alaska Trees and Shrubs, Agriculture Handbook, no. 410, USDA, Forest Service, 1972.

[7] W. M. Harlow, E. S. Harrar, J. W. Hardin, and F. M. White, Textbook of Dendrology, McGraw-Hill, New York, NY, USA, 8th edition, 1996.

[8] K. O. Hutchison, Alaska's Forest Resource, Resource Bulletin PNW-19, USDA, Forest Service, Juneau, Alaska, USA, 1967.

[9] J. Yarie, E. Kane, and M. Mack, Aboveground Biomass Equations for the Trees of Interior Alaska, AFES Bulletin, no. 115, University of Alaska, 2007.

[10] J. A. Helms, The Dictionary of Forestry, The Society of American Foresters, Bethesda, Md, USA, 1998.

[11] J. Nelder and R. Wedderburn, "Generalized linear models," Journal of the Royal Statistical Society. Series A, vol. 135, no. 3, pp. 370-384, 1972.

[12] A. Kozak and R. C. Yang, "Equations for estimating bark volume and thickness of commercial trees in British Columbia," Forestry Chronicle, vol. 57, no. 3, pp. 112-115, 1981.

[13] S. R. Gevorkiantz and L. P. Olsen, Composite Volume Tables for Timber and Their Application in the Lake States, Technical Bulletin, no. 1104, USDA, Forest Service, 1955.

[14] D. A. Belsley, E. Kuh, and R. E. Welsch, Regression Diagnostics: Identifying Influential Data and Sources of Collinearity, John Wiley \& Sons, New York, NY, USA, 1980.

[15] K. Van Cleve, L. Oliver, R. Schlentner, L. A. Viereck, and C. T. Dyrness, "Productivity and nutrient cycling in taiga forest ecosystems," Canadian Journal of Forest Research, vol. 13, no. 5, pp. 747-766, 1983.

[16] R. Zweifel and R. Häsler, "Frost-induced reversible shrinkage of bark of mature sub alpine conifers," Agricultural and Forest Meteorology, vol. 102, no. 4, pp. 213-222, 2000.

[17] J. D. Hale, "Thickness and density of bark trends of variation for six pulpwood species," Pulp and Paper Magazine of Canada, vol. 56, no. 13, pp. 113-117, 1955.

[18] E. T. Dimitrov, "Mathematical models for determining the bark volume of spruce in relation to certain mensurational characteristics," Forestry Abstract, vol. 37, pp. 62-81, 1976.

[19] R. A. Gregory and P. M. Haack, Equations and Tables for Estimating Cubic-Foot Volume of Interior Alaska Tree Species, Research Note NOR-6, USDA, Forest Service, 1964.

[20] F. R. Larson and K. C. Winterberger, Tables and Equations for Estimating Volumes of Trees in the Susitna River Basin, Alaska, Research Note PNW-RN-478, USDA, Forest Service, 1988. 

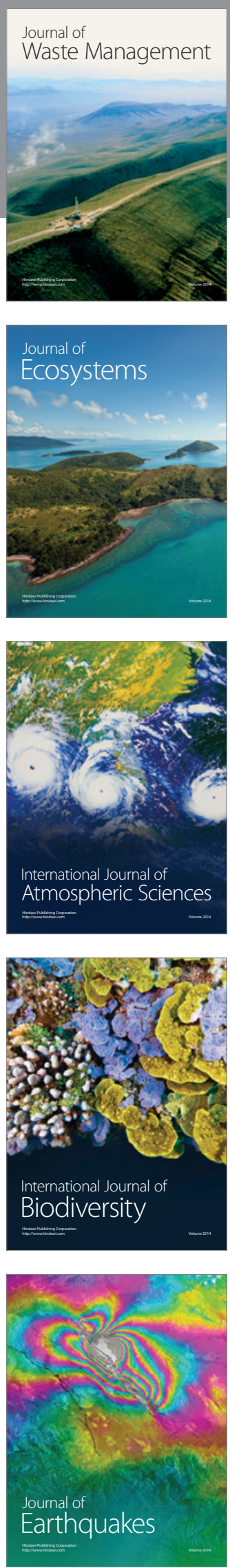
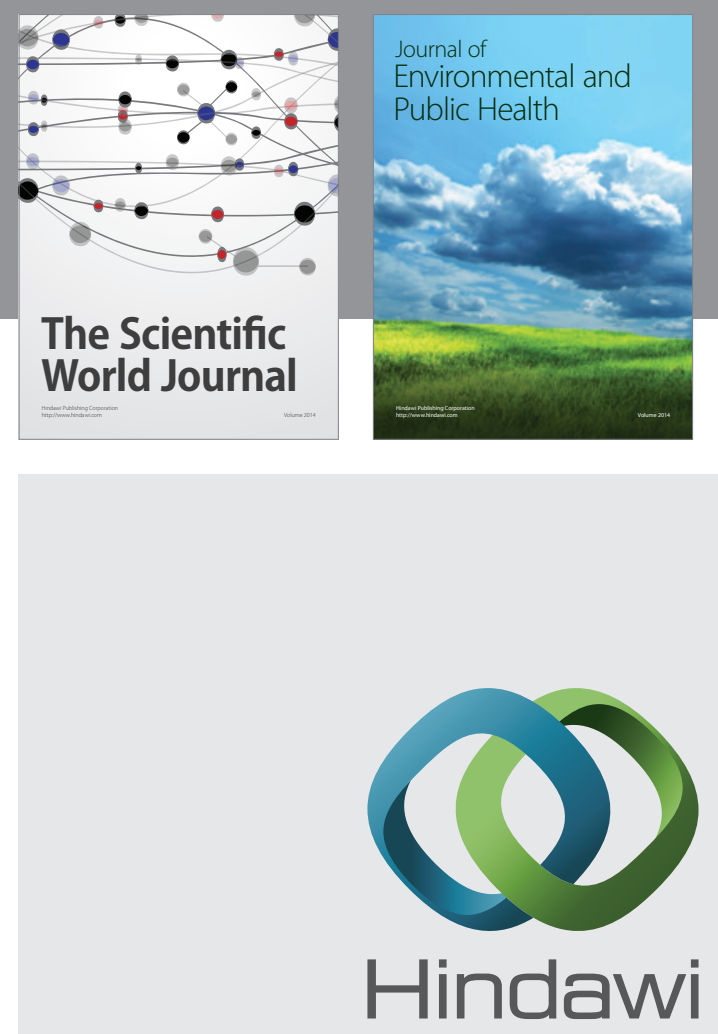

Submit your manuscripts at

http://www.hindawi.com
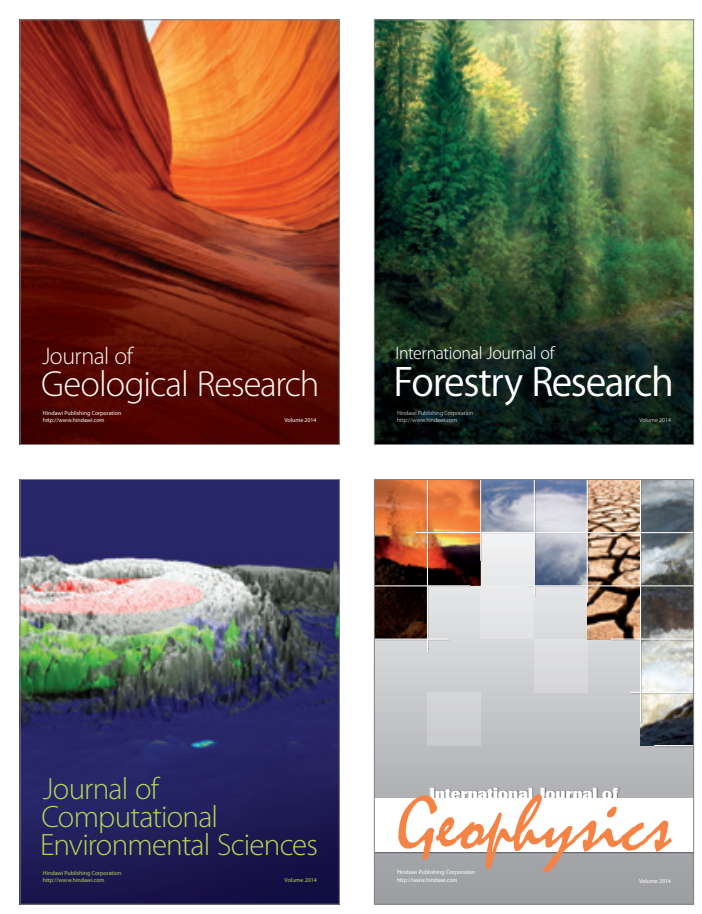
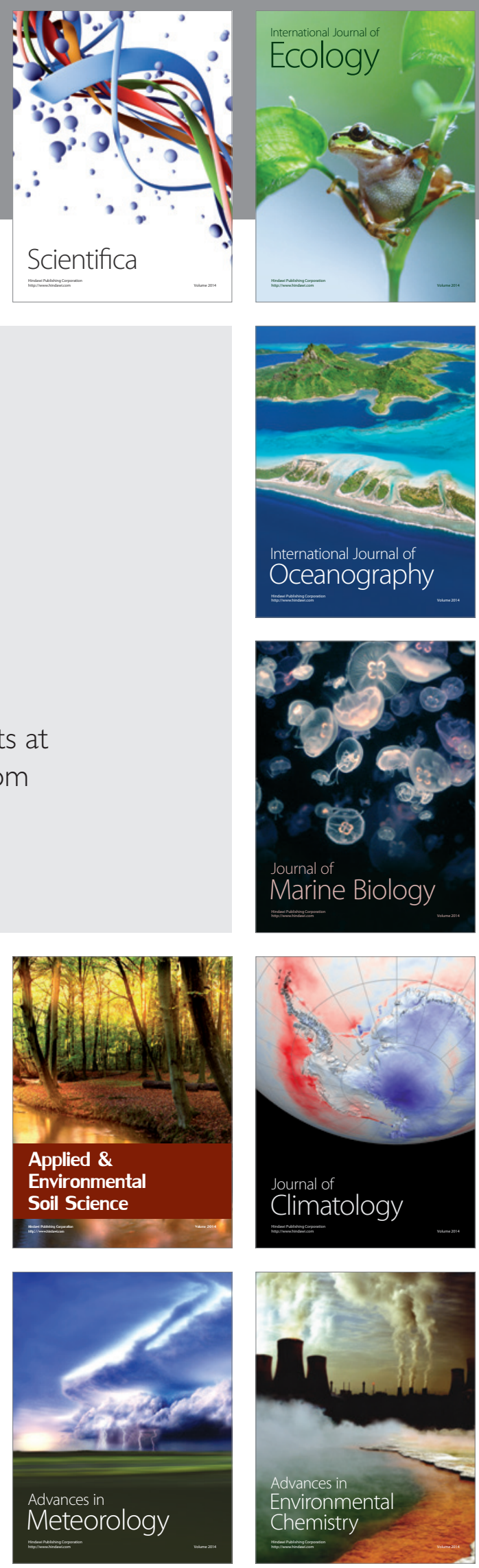